\title{
Rethinking Chronic Pain Treatment with Opioids
}

\author{
NIKUNJA B. PATI*, V. R. M. GUPTA, V. MAYASA ${ }^{1}$, SWAPNA VELIVELAAND MD. ASHWAQ HUSSAIN ${ }^{1}$ \\ Department of Pharmaceutics, ${ }^{1}$ Department of Pharmacology, Pulla Reddy Institute of Pharmacy, Jinnaram (M), Medak-502 \\ 313, India
}

\author{
Nikunja, et al.: Rethinking Chronic Pain Treatment with Opioids
}

\begin{abstract}
Opioid analgesics are defined as drugs that stimulate opioid receptors, primarily used in the treatment of moderate to severe pain. Since the discovery of opioids, they are considered as the most effective drugs for the pain relief. Even today, they are considered as the standard care in some of the countries for different pain conditions. Controversy remains for the treatment of long term pain in non-cancer and cancer patients. The main concerns with such treatment option are abuse liability, uncertainties in safety and effectiveness. Due to the abuse and dependence of opioids, regulatory restrictions were posed even though they have clinical use. Many legal regulatory authorities have provided guidelines for their use in the long term treatment. Even today, the great challenge exists with clinical community to deal with abuse and addiction of these opioid drugs, finally leading to limited usage of the opioids for treatment. This review focuses on the pain signalling and opioid pharmacology, opioid use in the chronic and cancer pain, different opioid drugs and their selection, drawbacks with these opioids drugs and strategies and approaches towards their effective use. If these opioidal drugs are prescribed with precautions under continuous observation and follow up for patients, definitely the central opioid analgesics would be best medication for chronic and cancer pains.
\end{abstract}

Key words: Opioids, severe pain cancer, non-malignant pain, dependence, strategies, circadian rhythm

Pain is an unpleasant sensation that can range from mild, localized discomfort to agony. The International Association for the Study of Pain's widely used definition states, "pain is an unpleasant sensory and emotional experience associated with actual or potential tissue damage, or described in terms of such damage"[1-2]. Pain mechanism is a complex phenomenon in which pain is induced by numerous pain modulating systems $^{[2]}$, sensitized by the neurophysiological systems. Pain can be influenced by the different factors like psychological conditions, health status and sociological factors ${ }^{[3]}$.

Pain is classified into two types, acute and chronic pain. If the pain persists for less than a month is called as acute pain. Clinically, if the pain persists more than three months after the injury, it is called as chronic pain $^{[4,5]}$. This type of pain may or may not be driven by the tissue injury. The two forms of pains are nociceptive and neuropathic pain ${ }^{[5-7]}$. Stimulation of the pain receptors is considered as the nociceptive pain whereas damage or dysfunctional to the central and peripheral nervous system is considered as the neuropathic pain.

\section{Pain signalling and inhibition pathways:}

Inflammatory mediators like bradykinin, serotonin, prostaglandins and cytokines ${ }^{[8]}$ are released from

*Address for correspondence

E-mail: nikunjapatipharmacy@gmail.com

November-December 2017 damaged tissues, which stimulate nociceptors ${ }^{[8-10]}$. Nociceptors are the specialized sensory receptors responsible for the detection of noxious (unpleasant) stimuli, transforming the stimuli into electrical signals, which are then conducted to the central nervous system (CNS) by primary afferent $A \delta, C$ and $A \beta$ fibers that are distributed throughout the body ${ }^{[10]}$. They can be stimulated by mechanical, thermal or chemical stimuli, called as primary sensitization. $\mathrm{A} \delta$ and $\mathrm{C}$ fibres transmit information to nociceptive specific neurons in Rexed laminae I and II of the dorsal horn in spinal cord, in addition to projections to other laminae. Primary afferent terminals release a number of excitatory neurotransmitters including glutamate and substance $\mathrm{P}[10-13]$.

Spinothalamic and spinoreticular tract are the two important pathways that carry signals to the higher centers of the brain. Spinothalamic tract is important

This is an open access article distributed under the terms of the Creative Commons Attribution-NonCommercial-ShareAlike 3.0 License, which allows others to remix, tweak, and build upon the work non-commercially, as long as the author is credited and the new creations are licensed under the identical terms

Accepted 30 August 2017

Revised 18 February 2017

Received 07 October 2016

Indian J Pharm Sci 2017;79(6):849-857 
pathway for pain localization that innervates in the periaqueductal grey (PAG) matter and somatosensory cortex ${ }^{[14]}$. The commonest areas activated in the brain includes the primary and secondary somatosensory cortex (S1 and S2), insular, anterior cingulate cortex, prefrontal cortex and the thalamus, demonstrating that these areas are all important in pain perception ${ }^{[15,16]}$. Pain can be inhibited at the spinal cord level via descending inhibition at higher centers of the brain $^{[14-17]}$. The higher centers like PAG in the midbrain and the rostral ventromedial medulla (RVM) have higher concentrations of opioid and endogenous receptors, which are the two important areas of the brain involved in descending inhibitory modulation ${ }^{[17]}$. Descending pathways project to the dorsal horn and inhibit pain transmission. These pathways are monoaminergic, utilizing noradrenaline and serotonin as neurotransmitters ${ }^{[8,18]}$.

\section{Opioids and opioid pharmacology:}

Opioids are the alkaloids, derived from Papaver somniferum (opium poppy). Opioid receptors are found peripherally and throughout the CNS. Most opioids are agonists; bind to the receptors present number of opioid in cells and triggers a response. There are huge receptors in the body that mediate analgesic action $^{[19-21]}$. Most chosen opioid analgesics for chronic pain treatment include morphine, hydromorphone, fentanyl, tramadol, oxycodone and buprenorphine ${ }^{[19]}$.

The opioids are characterized by the interactions with opioid receptors like $\mu, \delta, \kappa$ receptors ${ }^{[20-22]}$. These receptors belong to the family of G-protein coupled receptors (GPCRs) and activate inhibitory cyclic AMP or by ion channel signaling ${ }^{[20]}$. Morphine acts by $\mu$-receptors ${ }^{[21]}$. These $\mu$-receptors are distributed in the pre and postsynaptic sites of the spinal cord dorsal horn, brain stem, thalamus and cortex ${ }^{[21]}$. They are also distributed in the PAG, nucleus raphe magnus and the rostral ventral medulla the important sites for descending inhibition ${ }^{[22]}$.

Although three types of receptors are present, majority of the opioids acts by binding to the $\mu$-receptors. So they are called as $\mu$ agonists like morphine, oxycodone and codeine ${ }^{[21,23]}$. Naltrexone and nalaxone are considered as antagonists, as these reverse the agonistic action so they are called as agonist-antagonist drugs $^{[24]}$. Partial agonis ${ }^{[25]}$ produces a ceiling agonistic activity up to certain extent and further additional dose does not produce any additional effect. At the cellular levels, opioids act by decreasing the calcium influx thereby decreasing the pre-synaptic neurotransmitter release, i.e., substance P. They also act by enhancing the efflux of potassium ions result in hyperpolarization of postsynaptic neurons and thereby decreasing the synaptic transmission, or by inhibiting adenylate cyclase (AC), the enzyme which converts adenosine triphosphate (ATP) to cyclic adenosine monophosphate (cAMP). Opioids also act by inhibiting the GABAergic transmission in the local circuit resulting in the excitement of the descending inhibitory circuit ${ }^{[10]}$.

The drugs act specifically by binding to the opioid receptors which are distributed throughout the body mediating the pain by both CNS and peripheral nervous system. Endogenous peptides like endorphins also bind to the opioid receptors playing a role in pain modulation, mood and stress induction ${ }^{[17]}$. Drug liabilities of the opioid drugs are mainly based on the drug interactions to the $\mu$ receptors.

Opioids are the effective drugs used for the treatment of acute pains, chronic cancer pains and severe pain conditions $^{[26]}$. In spite of their medical use they were considered as drug of abuse and addiction ${ }^{[27,28]}$. Different opioid drugs for pain management have been shown in Table $1^{[28-35]}$, acting via different receptors. Opioids act by binding to the receptors by acting centrally or by peripheral mechanisms along with array of side effects like constipation, miosis, somnolence, respiratory depression. Hyperalgesia, tolerance, dysphoria and euphoria are produced by central action ${ }^{[35]}$. Sometimes, repeated administrations of these opioids may result in craving and with positive mood effects such as euphorigenic or pleasurable effects ${ }^{[30]}$. These outcomes may sometimes result in the addictive effect in the presence or absence of pain as well as chances of physical dependence and sometimes withdrawal also accompanies ${ }^{[36]}$. The pain signalling and opioid pharmacology ${ }^{[37]}$ has been shown in the fig. 1 .

\section{Chronic pain treatment with opioid analgesics:}

With the increased prevalence rate of chronic pain conditions, opioids are routinely prescribed for the treatment. There has been observed a massive increase in the number of opioid prescriptions in past two decades $^{[38]}$. The use of opioids remains controversial due to concerns about side effects, long-term efficacy, functional outcomes, and the potential for drug abuse and addiction ${ }^{[38-40]}$. Complicated regulatory and legal scrutinies on opioids are yet another challenge with prescribing of opioid drugs ${ }^{[4]}$. Even though there 


\begin{tabular}{|c|c|c|c|c|}
\hline Opioid drug & Sch. & Mechanism of action & Pain conditions & Adverse effects \\
\hline Morphine ${ }^{[28]}$ & 1 & $\begin{array}{l}\text { High affinity to } \mu \text {-opioid } \\
\text { receptor. Short-acting and } \\
\text { long acting formulations }\end{array}$ & $\begin{array}{c}\text { Second line for mild to } \\
\text { moderate pain and first line } \\
\text { for severe pain. Management } \\
\text { of severe cancer pain, severe } \\
\text { dyspnea }\end{array}$ & $\begin{array}{c}\text { Nausea and vomiting, } \\
\text { detachment and euphoria }\end{array}$ \\
\hline Hydromorphone ${ }^{[29]}$ & II & Similar to morphine & $\begin{array}{l}\text { Second line for mild to } \\
\text { moderate pain and first line } \\
\text { for severe pain }\end{array}$ & $\begin{array}{l}\text { Dose-related respiratory } \\
\text { depression, euphoria, miosis, } \\
\text { urinary retention, circulatory } \\
\text { depression }\end{array}$ \\
\hline Fentanyl[30] & II & $\begin{array}{l}\text { Strong agonist at the } \mu \text {-opioid } \\
\text { receptors }\end{array}$ & $\begin{array}{l}\text { Second line for severe pain. } \\
\text { Breakthrough pain, used as } \\
\text { part of anesthesia to help } \\
\text { prevent pain after surgery }\end{array}$ & $\begin{array}{l}\text { Slowed breathing; } \\
\text { slow heart rate; } \\
\text { muscle stiffness, } \\
\text { high blood pressure }\end{array}$ \\
\hline Tramadol[31] & IV & $\begin{array}{c}\text { Weak } \mu \text {-opioid receptor } \\
\text { agonism and enhances } \\
\text { serotonergic and adrenergic } \\
\text { pathways }\end{array}$ & $\begin{array}{l}\text { First line for mild to moderate } \\
\text { pain. Low back pain, } \\
\text { postoperative, osteoarthritis, } \\
\text { and neuropathic pain }\end{array}$ & $\begin{array}{l}\text { Respiratory depression, } \\
\text { anaphylactoid reactions, } \\
\text { renal and hepatic impairment }\end{array}$ \\
\hline Tapentadol HCl[69,70] & II & $\begin{array}{c}\mu \text {-opioid receptor agonism } \\
\text { and norepinephrine reuptake } \\
\text { inhibition }\end{array}$ & $\begin{array}{l}\text { Post-operative pain, diabetic } \\
\text { neuropathy }\end{array}$ & $\begin{array}{c}\text { Life threatening respiratory } \\
\text { depression; elderly and } \\
\text { debilitated patients. Chronic } \\
\text { pulmonary disease, } \\
\text { hypotensive effect } \\
\text { Renal and hepatic impairment. } \\
\text { Spasm of the sphincter of Oddi } \\
\text { risk }\end{array}$ \\
\hline Oxycodone ${ }^{[32]}$ & II & $\begin{array}{c}\text { k-opioid receptors, oxycodone } \\
\text { is metabolized in the liver to } \\
\text { oxymorphone, which binds to } \\
\mu \text {-opioid receptors }\end{array}$ & $\begin{array}{l}\text { Second line for mild to } \\
\text { moderate pain and first line } \\
\text { for severe pain. } \\
\text { Breakthrough pain }\end{array}$ & $\begin{array}{l}\text { Mental/mood changes, } \\
\text { stomach/abdominal pain, } \\
\text { slow/shallow breathing, } \\
\text { unusual drowsiness }\end{array}$ \\
\hline Buprenorphine ${ }^{[33]}$ & III & $\begin{array}{l}\text { Complex and unclear, slowly } \\
\text { binds to and slowly dissociates } \\
\text { from the } \mu \text {-receptor. Partial } \\
\text { agonist at } \mu \text { - receptors. } \\
\text { Antagonist at k-receptors, an } \\
\text { agonist at } \delta \text {-receptors, and } \\
\text { a partial agonist at ORL-1 } \\
\text { (nociception) receptors }\end{array}$ & Moderate to severe pain & $\begin{array}{l}\text { Physical dependence, dry } \\
\text { mouth, miosis, orthostatic } \\
\text { hypotension }\end{array}$ \\
\hline Methadone ${ }^{[34]}$ & II & $\begin{array}{l}\text { Levomethadone is a } \\
\text { full } \mu \text {-opioid agonist. } \\
\text { Dextromethadone binds to } \\
\text { the glutamatergic NMDA as } \\
\text { antagonist }\end{array}$ & $\begin{array}{l}\text { Third line for severe pain. } \\
\text { Maintenance therapy or to } \\
\text { help with detoxification } \\
\text { in people with opioid } \\
\text { dependence }\end{array}$ & $\begin{array}{c}\text { Sedation, constipation, } \\
\text { sweating, fatigue, prolongs QT } \\
\text { interval }\end{array}$ \\
\hline Pethidine $^{[35]}$ & II & $\begin{array}{l}\text { Agonist at the } \mu \text {-opioid } \\
\text { receptor }\end{array}$ & $\begin{array}{c}\text { Widely used opioid in } \\
\text { labor and delivery, against } \\
\text { diverticulitis }\end{array}$ & $\begin{array}{l}\text { Respiratory depression, } \\
\text { sedation, serotonin syndrome }\end{array}$ \\
\hline
\end{tabular}

NMDA: N-methyl-D-aspartate receptor

is modest evidence on pain relief in chronic nonmalignant pains (CNMP), one of the major concerns about not prescribing the opioids is that, absence of epidemiological evidence on the pain relief.

Medical use of the opioids does not create addicts but the restriction of these medications certainly hurts the medical patients. Opioids are sometimes taken in combination with non-opioids. A combination of treatments have been proved to be the best option ${ }^{[22,43]}$. Opioids may be useful for patients who do not respond to the first line treatments or who have moderate to severe pain, but are only be recommended on an "as needed" basis.

Opioids are also recommended to treat acute pain related to surgery and other medical procedures along with chronic non-malignant and breakthrough pain ${ }^{[4]}$. Persistent pain is usually treated with long-acting opioids that are released into the body slowly and act for longer duration ${ }^{[45]}$. These are supposed to be taken around-the-clock on a regular schedule, whether or 


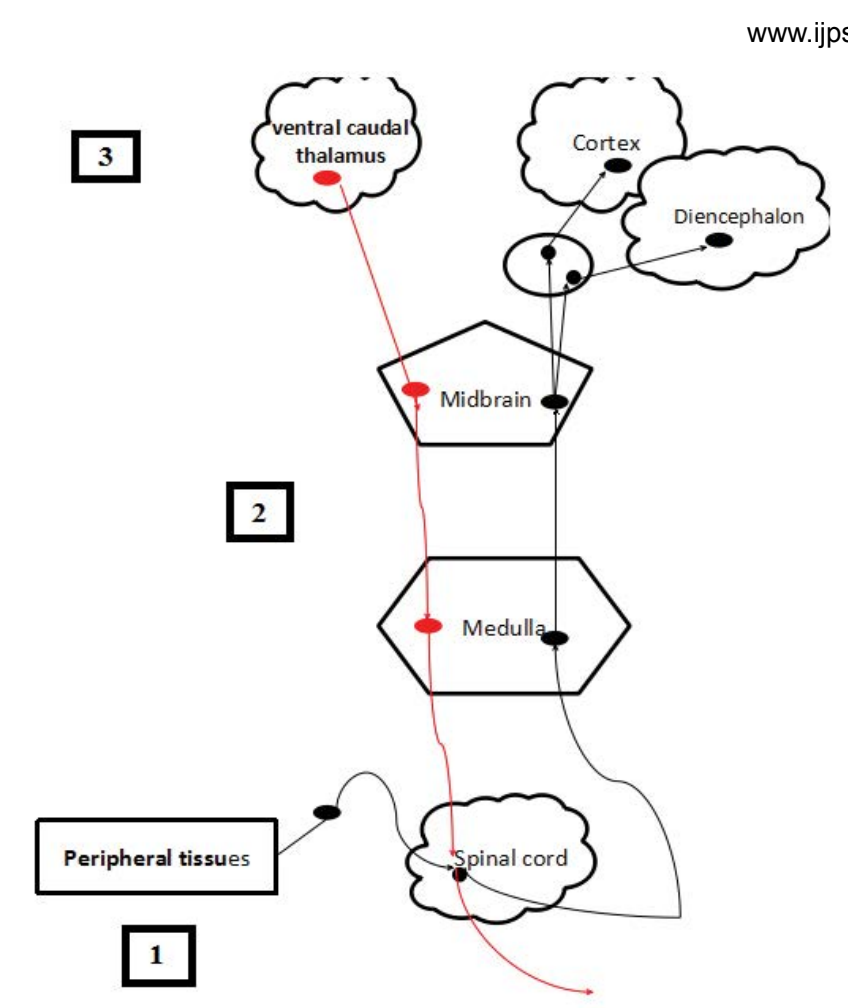

Fig. 1: Pain signaling and opioid pharmacology ${ }^{[2,53]}$ 1. Possible direct action of opioids on peripheral tissue; 2. inhibition occurs at spinal cord; 3 . possible site action

not pain exists at the time. If there are episodes of breakthrough pain, a second short-acting opioid may be prescribed as well ${ }^{[42,46]}$. Short-acting opioids work more quickly and do not stay in the body for longer time. Little or no support for the efficacy of opioid treatment was reported successfully as evidence in favour of opioids is not always consistent, and when supportive, only supports this treatment for short periods. Many randomized controlled trials have also demonstrated analgesic efficacy of short-term, but not long-term, treatment of chronic pain ${ }^{[47,48]}$.

There has been wide range of prescribing patterns of opioids for CNMP by the physicians. Considerable numbers of physicians are unenthusiastic or reluctant to prescribe long-acting opioids to treat CNMP, even when it may be medically appropriate ${ }^{[30]}$. The other mainstays for avoiding these drugs are opioid-induced hyperalgesia. But till now, there has been no sufficient clinical evidence of the same ${ }^{[49]}$. Methodological limitations like ethical and practical challenges have also limited the usage of opioids. Even today these drugs are prescribed only with limited evidence. Further studies like practical clinical trials on proper utilizing these drugs will certainly boost up the proper guidelines framing.

Different guidelines ${ }^{[50]}$ are in use for the treatment of chronic pain like AAFP-2002 $2^{[51]}$, OQP-2003 ${ }^{[52]}$, CDC-2017 ${ }^{[53]}$. These guidelines mainly focuses on the selection of patients, therapy for proper monitoring and assessment of drug related behaviour and the strategies for the alternative therapies for the clinicians. The opioid treatment should be initially started like a trial and then extended for the other therapies to benefit patients. And also clinicians should know the burdens of the therapies by their trials before the initiation of the trail. By considering the recent guidelines for the prescribing opioids would be beneficial for the pain management.

In patients with chronic pain prescribed long-term opioid therapy, the effectiveness of risk mitigation strategies $^{[54,55]}$ include, 1) opioid management plans, 2) patient education, 3) urine drug screening, 4) use of prescription drug monitoring program data, 5) use of monitoring instruments, 6) more frequent monitoring intervals, 7) pill counts, and 8) use of abuse-deterrent formulations (ADFs) on outcomes related to overdose, addiction, abuse, or misuse, all these should be adopted.

Long-acting morphine is the preferred as initial drug among opioids, although several alternatives are available. If morphine doesn't work significantly, physicians may consider switching to different opioid analgesics ${ }^{[6]}$. The next analgesics preferred include tramadol, buprenorphine, methadone, diamorphine, fentanyl, hydrocodone, oxycodone, tapentadol, and pethidine. Hydrocodone is the most commonly prescribed for a variety of painful conditions, including dental and injury-related pain. Morphine is often used before and after surgical procedures to alleviate severe pain ${ }^{[57,58]}$. Tapentadol is indicated for the management of moderate to severe chronic pain and specially for neuropathic pain associated with diabetic peripheral neuropathy (DPN) in adults ${ }^{[57]}$. Tramadol, in combination with acetaminophen are recommended for chronic low back pain ${ }^{[59]}$. This medication is advised alone or in combination. Strong opioids may be indicated for chronic low back pain when other pain relief treatments are unsuccessful. Long term efficacy of opioids for lower back pain remains unclear.

The concerns about the clinical usage of opioids include tolerance, pain sensitivity to opioids, routes of administrations. The irony is we normally believe that all types of pain are equally responded by opioids. However, difference in receptor selectivity can certainly exploited to manage different types of pain. No clinical evidence on differential selectivity and efficacy could be established yet. 


\section{Opioid insensitive pain ${ }^{[60]}$ :}

If the pain does not respond progressively to increasing opioid dose, it is called opioid insensitive pain. This may be due to nerve compression and nerve destruction. A working rule for better medical indication for opioids in case of pain in a numb area due to a damaged nervous system, opioids are less likely to relieve pain, except at doses with greater clinical effects. So, non-cancer and chronic cancer pains are not always relieved by the opioids.

\section{Opioids in non-cancer pain:}

Opioids are prescribed to the non-cancer patients only if there is no alternative medication to relieve pain. The use of opioids in the non-cancer pain should be properly addressed to the society because there are oppositions over the usage of opioids as these are considered as drugs for addiction ${ }^{[61]}$.

\section{Physical dependence and opioid withdrawa ${ }^{[62,63]}$ :}

Even though there are limited studies on the physical dependence. Most of studies have reported high prevalence for substance abuse among the persons with chronic pain inferred by high drug addiction. Occurrence of opioid withdrawal can occur in both the addicted patient and the patient who has opioid dependence but is not experiencing total opioid addiction. When an opioid is stopped or the dose is suddenly reduced, both types of patients experience withdrawal symptoms such as, sweating, chills, muscle and joint pain, nausea, vomiting, diarrhoea, restlessness and insomnia. Fear of these unpleasant and painful opioid withdrawal symptoms makes it difficult for the addict to stop using and begin the recovery process.

The time it takes to become physically dependent varies with each individual. Opioid withdrawal reactions are very uncomfortable but are not life-threatening. Symptoms usually start within $12 \mathrm{~h}$ of last heroin usage and within $30 \mathrm{~h}$ of last methadone exposure ${ }^{[64]}$. To avoid such withdrawal reactions, it is necessary to discuss with the doctor before stopping any such opiate medication and bring the dose down slowly.

\section{Opioids incomparision to other analgesics ${ }^{[65]}$ :}

The opioid analgesics are advantageous over other non-opioid analgesics in few respects. As, the opioid analgesics act both centrally and peripherally as well ${ }^{[66]}$, there is no ceiling effect is associated with opioids. Risk of severe gastrointestinal symptoms, including ulceration and bleeding is associated with long term treatment of non-steroidal antiinflammatory drugs (NSAIDs). Moreover, now opioid drugs are available as schedule III, IV, V drugs, many of which are devoid of their major side effects like addiction, dependence, tolerance and respiratory depression. NSAIDs are commonly used to treat nociceptive pain and inhibit prostaglandin production. Whereas, opioids are used to treat malignant pain in the elderly and can also be used for treatment of neuropathic non-malignant pain.

\section{STRATEGIES}

\section{New generation opioid analgesics:}

Opioids are the best option for treatment of moderate to severe pain has never been denied. However, opioids are underutilized, due to potential risk of adverse effects, abuse, tolerance, withdrawal, and liability. Suboptimal use of opioids can lead to unrelieved pain, leading to poor patient outcome and potential life-threatening complications. These problems can be overcome by using possible strategies in opioid treatment. One strategy aimed at improving the compliance of $\mu$-opioid receptor (MOR) agonists is to combine MOR agonism with monoamine reuptake inhibition. Tapentadol is such next generation opioid analgesic. Tapentadol is centrally acting analgesic with MOR agonist and NRI actions. It was approved by the US Food and Drug Administration (US FDA) in November, 2008, by the Medicines and Healthcare products Regulatory Agency (MHRA) of the UK in February 2011 and by the Therapeutic Goods Administration (TGA) of Australia in December 2010. It has ten-fold affinity for MOR, compared with $\delta$ - and $\kappa$-opioid receptors. This dual mode of action helps it to attain its opioid sparing effect, contribute to reduce in some of the typical opioid related adverse effects and results in improved compliance ${ }^{[67,68]}$. Tapentadol is indicated in moderate to severe chronic pain and neuropathic pain associated with DPN in adults ${ }^{[67,71]}$. But it is not intended for use as an analgesic for acute pain and mild pain ${ }^{[68]}$. In comparison to morphine it was proved to reduce pain more effectively. Its general potency is somewhere between that of tramadol and morphine. It has been studied for effective management of pain associated with osteoarthritis and low back pain ${ }^{[69,71]}$, it was found to be similar to that by oxycodone $(20-50 \mathrm{mg}$, twice daily) with a superior gastrointestinal tolerability profile and fewer treatment discontinuations. A phase three trial in patients with painful DPN showed the efficacy of tapentadol in neuropathic pain. There are inadequate data to support its use for cancer pain ${ }^{[71]}$. 
A clinical trial with combination of tapentadol with pregabalin for neuropathic pain and low back pain is currently underway investigation.

The most common adverse events in the trials were nausea, dizziness, vomiting, somnolence, constipation and pruritus. These events seemed to be dose-related. No significant respiratory depression was seen in case of tapentado[ ${ }^{[70,71]}$. Studies suggest that it does not cause opioid-like withdrawal symptom on abrupt discontinuation of the drug after long-term therapy. Even if they do occur, these symptoms are mild. Long-term therapy was not found to be associated with clinically significant changes in hepatic and renal parameters or electrocardiogram (ECG) under laboratory studies ${ }^{[72]}$.

\section{Strategies for effective opioid risk mitigation:}

These risk mitigation strategies are needed with the goal of improving the safe use of long acting opioid analgesics while ensuring continued access to these medications for patients in need of them ${ }^{[73]}$. Authenticated guidelines for opioid treatment are available and supposed to be followed. Base line assessment, starting non-opioid therapy, then first line opioid drugs, second line of opioid drugs, immediate release opioids, controlled release opioids, initial titration, break through dosing and office visits are the part of such standard guidelines for the opioid usage ${ }^{[74]}$.

In USA authorized prescription drug monitoring programs (PDMPs) are followed. PDMPs serve a multitude of functions, including assisting in patient care, providing early warning of drug abuse epidemics (especially when combined with other data), evaluating interventions, and investigating drug diversion and insurance fraud ${ }^{[75]}$.

FDA has also included under risk evaluation and mitigation strategy (REMS), the need of training for health care professionals who prescribe long acting opioid analgesics on proper prescribing practices and also to distribute educational materials to prescribers and patients on the safe use of these powerful pain medications ${ }^{[76]}$. Modern pain therapy widely follows the World Health Organization (WHO) guidelines using a three-step 'ladder' for pain relief. Fig. 2 represents this escalating step scheme includes the administration in the order non-opioids, mild opioids and strong opioids, and adjuvant at any step ${ }^{[77]}$.

\section{Novel abuse resistant controlled drug delivery systems ${ }^{[78]}$ :}

The ideal analgesic formulation would be effective against a broad range of pain types. It should have

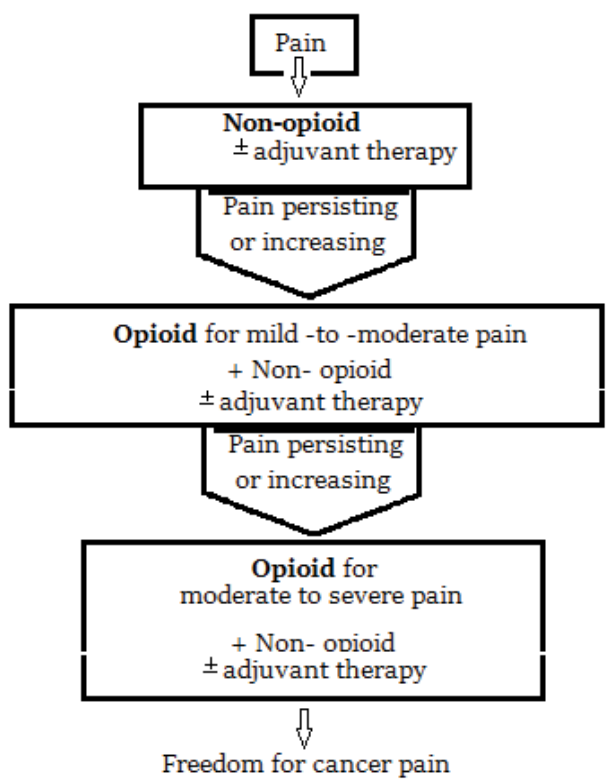

Fig. 2: Three-step 'ladder' for pain relief by WHO

a rapid onset and controllable duration; be free of undesirable side effects such as respiratory depression and sedation lack clinically problematic metabolites; and be readily accessible and cost effective. Research work on formulations based on novel polymer matrix system comprising of biocompatible, biodegradable, pharmaceutically acceptable, readily available and inexpensive materials that can be used to prepare novel drug delivery systems ${ }^{[79]}$ are currently in progress, like Buprenorphine SR ${ }^{\circledR}$, MS Contin ${ }^{\circledR}$ and Avinza ${ }^{\circledR}$ for morphine. The topical analgesics, like fentanyl patch, buprenorphine patch and transdermal formulations also have proved to have advantages of convenient, as well as an extended duration of effective use without the risk of first-pass metabolism. In addition, the novel polymer matrix formed into micro needles for controlled transdermal drug delivery using micro injection moulding processing techniques is also under study ${ }^{[78]}$. Other systems include extended-release liposome encapsulated formulation like for morphine Depodur $^{\circledR}$, EKR Therapeutics Inc, Cedar Knolls NJ. The pharmaceutical industry is also showing significant interest in developing such ADFs and the technology is progressing rapidly. ADFs hold promise as their abusedeterrent qualities continue to improve and as they become more widely available.

\section{Pain and circadian rhythm ${ }^{[79,80]}$ :}

Analgesics should be given 'by the clock' rather than 'on demand'. However, the chronobiological parameters like circadian pain rhythm, circadian efficacy of analgesics, and individual circadian need for analgesics 
are to be considered. The results of multitude of studies in chronobiology are not consistent. Therefore, further studies with standardized protocols are needed that allow assigning more consistent rhythms to diseases, pain causes, and analgesic efficacy of opioids. As different types of pain show different rhythms (highest pain intensities arising at different times of the day) analgesics should be dosed flexibly. It is also very important that drug therapy can be adjusted individually to the pain rhythm of the patient as well as to the type and cause of pain. A flexible dosage depending on pain intensity and rapid dose adjustment are essentials of a modern pain therapy. Therefore, opioids that are flexible to use are better suited to treat the individual pain of the patient than rigid modified release oral or transdermal systems.

Opioids have been prescribed for the management of acute to chronic pain since long time, although there are misbelieves and misconception over the opioid pharmacology, rationale and appropriate usage. Till date, most of the opioids were prescribed for the patients suffering with non-malignant pain. However, due to the advanced treatment strategies opioids can be safely extended to the non-cancer pains. Even studies have reported that drug abuse in very less to the cancer pain patients without the history of substance abuse.

Individualization of analgesic therapy and appropriate management of pain by the use of opioids along with non-opioid analgesics would be rightly successful. Selection of the right analgesics, right dose administration on right schedule to have maximum relief with minimum side effects would be our suggestion for the opioid use in the non-cancer patients. Individual titrations of the dose with combinations would reduce the adverse effects will be the key strategy for management of pain with these drugs. The complexity of clinical decision-making around long-term opioid therapy could be overcome by individualized assessments of the balance between benefits and harms, decisions related to opioid selection, dose initiation and titration strategies, integration of risk assessment and mitigation strategies, as well as consideration of the role of alternative, non-opioid therapies.

\section{Acknowledgments:}

The authors wish to thank the institutions who have provided encouragement and sufficient resources to development of this review.

\section{Conflict of interest:}

The authors report no declarations of interest.

\section{Financial support and sponsorship:}

Nil.

\section{REFERENCES}

1. https://www.iasp-pain.org/PublicationsNews/Content. aspx?ItemNumber $=\% 201673$.

2. Watson CPN. The phenomenon of pain. Pain Res Manag 2014;19:49-50.

3. Linton SJ, Shaw WS. Impact of psychological factors in the experience of pain. Phys Ther 2011;91:700-11.

4. https://medlineplus.gov/magazine/issues/spring11/articles/ spring11pg5-6.html.

5. Treede RD, Rief W, Barke A, Aziz Q, Bennett MI, Benoliel $\mathrm{R}$, et al. A classification of chronic pain for ICD-11. Pain 2015;156:1003-7.

6. Thakur M, Dickenson AH, Baron R. Osteoarthritis pain: nociceptive or neuropathic? Nat Rev Rheumatol 2014;10:374-80.

7. Seaman DR, Cleveland C 3rd. Spinal pain syndromes: nociceptive, neuropathic, and psychological mechanisms. J Manipulative Physiol Ther 1999;22:458-72.

8. Kidd BL, Urban LA. Mechanisms of inflammatory pain. Br J Anaesth 2001; 87:3-11.

9. Serpell M. Anatomy, physiology and pharmacology of pain. Surgery 2006;24:350-3.

10. Schaible HG, Ebersberger A, Natura G. Update on peripheral mechanisms of pain: beyond prostaglandins and cytokines. Arthritis Res Ther 2011;13:210.

11. Todd AJ. Neuronal circuitry for pain processing in the dorsal horn. Nat Rev Neurosci 2010;11:823-36.

12. Lorenzo LE, Ramien M, St Louis M, De Koninck Y, Ribeiroda-Silva A. Postnatal changes in the Rexed lamination and markers of nociceptive afferents in the superficial dorsal horn of the rat. J Comp Neurol 2008;508:592-604.

13. Lawson SN, Crepps BA, Perl ER. Relationship of substance $P$ to afferent characteristics of dorsal root ganglion neurones in guinea-pig. J Physiol 1997;505:177-91.

14. Willis WD, Westlund KN. Neuroanatomy of the pain system and of the pathways that modulate pain. J Clin Neurophysiol 1997;14:2-31.

15. Wiech K, Jbabdi S, Lin CS, Andersson J, Tracey I. Differential structural and resting state connectivity between insular subdivisions and other pain-related brain regions. Pain 2014;155:2047-55.

16. Ossipov MH, Dussor GO, Porreca F. Central modulation of pain. J Clin Invest 2010;120:3779-87.

17. Ossipov MH. The perception and endogenous modulation of pain. Scientifica 2012;2012:561761.

18. Marks DM, Shah MJ, Patkar AA, Masand PS, Park GY, Pae CU. Serotonin-norepinephrine reuptake inhibitors for pain control: premise and promise. Curr Neuropharmacol 2009;7:331-6.

19. Vella-Brincat J, Macleod AD. Adverse effects of opioids on the central nervous systems of palliative care patients. J Pain Palliat Care Pharmacother 2007;21:15-25. 
20. Al-Hasani R, Bruchas MR. Molecular mechanisms of opioid receptor-dependent signalling and behaviour. Anesthesiology 2011;115:1363-81.

21. Roux BT, Cottrell GS. G protein-coupled receptors: what a difference a 'partner' makes. Int J Mol Sci 2014;15:1112-42.

22. Ninković J, Roy S. Role of the mu-opioid receptor in opioid modulation of immune function. Amino Acids 2013;45:9-24.

23. Welch SP, Martin BR. Opioid and Nonopioid Analgesics. In: Craig CR, Stitzel RE, editors. Modern Pharmacology with Clinical Applications. 6th ed. Philadelphia, USA: Lippincott William \& Wilkins; 2004. p. 310-29.

24. Mannelli P. Agonist-antagonist combinations in opioid dependence: A translational approach. Dipend Patologiche 2010;5:17-24.

25. Helm S, Trescot AM, Colson J, Sehgal N, Silverman S. Opioid antagonists, partial agonists, and agonists/antagonists: the role of office-based detoxification. Pain Physician 2008;11:225-35.

26. Goodsell DS. The molecular perspective: morphine. Oncologist 2004;9:717-8.

27. Lynch ME, Fischer B. Prescription opioid abuse. Can Fam Physician 2011;57:1241-2.

28. Savage SR, Kirsh KL, Passik SD. Challenges in using opioids to treat pain in persons with substance use disorders. Addict Sci Clin Pract 2008;4:4-25.

29. https://lactmed.nlm.nih.gov/cgi-bin/sis/search2/ r?dbs+hsdb:@term+@rn+466-99-9:@odlactmed@/cgi-bin/ sis/search2/f?./temp/ XattGh:1@.

30. https://toxnet.nlm.nih.gov/cgi-bin/sis/search2/f?./ temp/ RUhZzy: 1 .

31. https://toxnet.nlm.nih.gov/cgi-bin/sis/search2/f?./ temp/ ntFWhJ:1.

32. Moradi M, Esmaeili S, Shoar S, Safari S. Use of oxycodone in pain management. Anesth Pain 2012;1(4):262-4.

33. Kahan M, Srivastava A, Ordean A, Cirone S. Buprenorphine: new treatment of opioid addiction in primary care. Can Fam Physician 2011;57(3):281-9.

34. https://toxnet.nlm.nih.gov/cgi-bin/sis/search2/f?./ temp/ cc8mjc: 1 .

35. Duthie DJR, Nimmo WS. Adverse effects of opioid analgesic drugs. Br J Anaesth 1987;59:61-7.

36. Baldini A, Von Korff M, Lin EH. A review of potential adverse effects of long-term opioid therapy: a practitioner's guide. Prim Care Companion CNS Disord 2012;14:2.

37. Al-Hasani R1, Bruchas MR .Molecular Mechanisms of opioid receptor-dependent signalling and behaviour. Anesthesiology 2011;115(6):1363-81.

38. Sehgal N, Manchikanti L, Smith HS. Prescription opioid abuse in chronic pain: a review of opioid abuse predictors and strategies to curb opioid abuse. Pain Physician 2012;15:ES67-92.

39. Manchikanti L, Fellows B, Ailinani H, Pampati V. Therapeutic use, abuse, and nonmedical use of opioids: A ten-year perspective. Pain Physician 2010;13:401-35.

40. Morgan MM, Christie MJ. Analysis of opioid efficacy, tolerance, addiction and dependence from cell culture to human. Br J Pharmacol 2011;164(4):1322-34.

41. Bolen J. Getting informed consent and agreement for treatment right: A legal perspective on key obligations for practitioners who use controlled substances to treat chronic pain. J Opioid Manag 2006;2:193-200.
42. Argoff CE, Silvershein DI. A Comparison of long- and shortacting opioids for the treatment of chronic noncancer pain: tailoring therapy to meet patient needs. Mayo Clin Proc 2009;84(7):602-12.

43. Gilron I, Bailey JM, Tu D, Holden RR, Weaver DF, Houlden RL. Morphine, gabapentin, or their combination for neuropathic pain. N Engl J Med 2005;352(13):1324-34.

44. Lewis NL, Williams JE. Acute pain management in patients receiving opioids for chronic and cancer pain. Contin Educ Anaesth Crit Care Pain 2005;5(4):127-9.

45. Gregory TB. How to safely prescribe long-acting opioids. J Fam Pract 2013;62:S12-8.

46. Beutlhauser T, Oeltjenbruns J, Schäfer M. Breakthrough pain and short-acting opioids. Anaesthesist 2013;62(6):431-9.

47. Elon Eisenberg MD, Ewan D. McNicol RPh, Daniel B. Carr MD. Efficacy and Safety of Opioid Agonists in the Treatment of Neuropathic Pain of Nonmalignant Origin. A Systematic Review and Meta-analysis of Randomized Controlled Trials. JAMA. 2005;293(24):3043-52.

48. McNicol ED, Midbari A, Eisenberg E. Opioids for neuropathic pain. Cochrane Database Syst Rev 2013;8:CD006146.

49. Angst MS, Clark JD. Opioid-induced hyperalgesia: a qualitative systematic review. Anesthesiology 2006;104:570-87.

50. Trescot AM, Boswell MV, Atluri SL, Hansen HC, Deer TR, Abdi S, et al. Opioid guidelines in the management of chronic non-cancer pain. Pain Physician 2006;9:1-39.

51. Drug Enforcement Administration. A joint statement from 21 health organizations and the Drug Enforcement Administration. Promoting pain relief and preventing abuse of pain medications: a critical balancing act. J Pain Symptom Manage 2002;24(2):147.

52. http://www.oqp.med.va.gov/cpg/cot/ot_base.htm.

53. https://www.cdc.gov/drugoverdose/prescribing/guideline. html.

54. Chou R, Turner JA, Devine EB, Hansen RN, Sullivan SD, Blazina I, et al. The effectiveness and risks of long-term opioid therapy for chronic pain: a systematic review for a National Institutes of Health Pathways to Prevention Workshop. Ann Intern Med 2015;162(4):276-86.

55. https://www.ncbi.nlm.nih.gov/books/NBK47095/.

56. Mercadante S, Casuccio A, Colderone L. Rapid switching from morphine to methadone in cancer patients with poor response to morphine. J Clin Oncol 1999;17:3307-12.

57. Vincent P. Morphine. Now. Am J Nurs 2015;115(4):72.

58. https://www.fda.gov/ForConsumers/ConsumerUpdates/ ucm095673.htm.

59. C Romanò CL, Romanò D, Lacerenza M. Antineuropathic and antinociceptive drugs combination in patients with chronic low back pain: a systematic review. Pain Res Treat 2012;2012:154781.

60. Terman GW, Loeser JD. A case of opiate-insensitive pain: malignant treatment of benign pain. Clin J Pain 1992;8(3):255-9.

61. Alford DP. Opioid prescribing for chronic pain achieving the right balance through education. N Engl J Med 2016;374:301-3.

62. Ballantyne JC, LaForge KS. Opioid dependence and addiction during opioid treatment of chronic pain. Pain 2007;129:235-55.

63. Kosten TR, George TP. The neurobiology of opioid 
dependence: implications for treatment. Sci Pract Perspect 2002;1(1):13-20.

64. http://printer-friendly.adam.com/content. aspx?productId=117\&pid=1\&gid=000949\&c_custid=802.

65. Becker DE, Phero JC. Drug therapy in dental practice: nonopioid and opioid analgesics. Anesth Prog 2005;52(4):140-9.

66. Trescot AM, Datta S, Lee M, Hansen H. Opioid pharmacology. Pain Physician 2008;11:S133-53.

67. Vadivelu N, Huang Y, Mirante B, Jacoby M, Braveman FR, Hines RL, et al. Patient considerations in the use of tapentadol for moderate to severe pain. Drug Healthc Patient Saf 2013;5:151-9.

68. Frampton JE. Tapentadol immediate release: a review of its use in the treatment of moderate to severe acute pain. Drugs 2010;70(13):1719-43.

69. Shah H, Bhavsar M, Kishoria N, Bonasi D, Pandya M, Jaishree SB. Oral Tapentadol as a premedication for the perioperative management of cardiac surgery. Int $\mathrm{J}$ Biomed Adv Res 2013;04(10):723-30.

70. Lange B, Kuperwasser B, Okamoto A, Steup A, Häufel T, Ashworth J, et al. Efficacy and safety of tapentadol prolonged release for chronic osteoarthritis pain and low back pain. Adv Ther 2010;27(6):381-99.

71. Coluzzi F, Raffa RB, Pergolizzi J, Rocco A, Locarini P, Cenfra N, et al. Tapentadol prolonged release for patients with multiple myeloma suffering from moderate-to-severe cancer pain due to bone disease. J Pain Res 2015;8:229-38.

72. Singh DR, Nag K, Shetti AN, Krishnaveni N. Tapentadol hydrochloride: A novel analgesic. Saudi J Anaesth 2013;7(3):322-6.

73. Brennan MJ. Update on prescription extended-release opioids and appropriate patient selection. J Multidiscip Healthc 2013;6:265-80.

74. http://www.agencymeddirectors.wa.gov/files/ opioidgdline.pdf.

75. Griggs CA, Weiner SG, Feldman JA. Prescription Drug Monitoring Programs (PDMPs): Examining Limitations and Future Approaches. West J Emerg Med 2015;16(1):67-70.

76. Brooks MJ. Mitigating the safety risks of drugs with a focus on opioids: are risk evaluation and mitigation strategies the answer? Mayo Clin Proc 2014;89(12):1673-84.

77. http://apps.who.int/iris/bitstream/10665/37896/1/92415 44821.pdf.

78. Leppert W, Krajnik M, Wordliczek J. Delivery systems of opioid analgesics for pain relief: A review. Curr Pharm Des 2013;19(41):7271-93.

79. Junker U, Wirz S. Review article: chronobiology: influence of circadian rhythms on the therapy of severe pain. J Oncol Pharm Pract 2010;16(2):81-7.

80. Schiessl C1, Schestag I, Sittl R, Drake R, Zernikow B. Rhythmic pattern of PCA opioid demand in adults with cancer pain. Eur J Pain 2010; 14(4):372-9. 